\title{
МІСЦЕ ТА РОЛЬ МЕДИЧНОГО ЗАБЕЗПЕЧЕННЯ В СИСТЕМІ ДЕРЖАВНОЇ СЛУЖБИ УКРАЇНИ З НАДЗВИЧАЙНИХ СИТУАЦІЙ
}

\author{
${ }^{1}$ Тернопільський національний медичний університет імені І. Я. Горбачевського МОЗ України, \\ м. Тернопіль, Україна \\ ${ }^{2}$ Аварійно-рятувальний загін спеціального призначення управління Державної служби України 3 \\ надзвичайних ситуацій у Тернопільській області, м. Тернопіль, Україна
}

\begin{abstract}
Мета: дослідити систему медичного забезпечення органів і підрозділів служби цивільного захисту, її завдання та ключові повноваження.

Матеріали і методи. Використано чинні нормативно-правові акти та керівні документи щодо організації медичного забезпечення в системі ДСНС. Методи дослідження: бібліосемантичний, аналітичний, системного підходу.

Результати. У статті визначають завдання медичної служби у контексті основних повноважень ДСНС щодо забезпечення реалізації державної політики з питань медичного та біологічного захисту населення в разі виникнення надзвичайних ситуацій; здійснення ліквідації медико-санітарних наслідків надзвичайних ситуацій, надання екстреної медичної допомоги у зоні надзвичайної ситуації (осередку ураження) постраждалим та рятувальникам, проведення заходів з медичного забезпечення прикріпленого контингенту, які здійснюють заклади охорони здоров'я сорери управління ДСНС. Розглядають головні напрями діяльності закладів охорони здоров'я ДСНС, а саме: лікувально-профрілактичний, санітарно-гігієнічний, організаційно-методичний, протиепідемічний, медичного постачання і медико-психологічної реабілітації.

Висновки. Медичне забезпечення в системі ДСНС $є$ невід'ємною частиною повноважень, покладених на службу цивільного захисту. Безпосередні заходи з медичного забезпечення безперервно здійснюють заклади охорони здоров'я сорери управління ДСНС як у пунктах постійної дислокації органу, підрозділу служби цивільного захисту, так і під час виконання завдань за призначенням у зоні надзвичайної ситуації (осередку ураження) при ліквідації їі наслідків й на шляху медичної евакуації. Медико-санітарну допомогу надають відповідно до державних соціальних нормативів та галузевих стандартів у сфері охорони здоров'я та вона включає весь комплекс лікувальнопрофілактичних заходів на всіх рівнях надання допомоги у тісній взаємодії з закладами охорони здоров'я та медичними підрозділами інших центральних органів виконавчої влади.
\end{abstract}

КЛЮЧОВІ СЛОВА: медичне забезпечення; служба цивільного захисту; Державна служба України 3 надзвичайних ситуацій.

Державна служба України 3 надзвичайних ситуацій (ДСНС) є центральним органом виконавчої влади, діяльність якого спрямовується і координується Кабінетом Міністрів України (КМУ) через Міністра внутрішніх справ.

Основні завдання ДСНС:

1) реалізація державної політики у сфері цивільного захисту, захисту населення і територій від надзвичайних ситуацій, запобігання їх виникненню, ліквідації наслідків надзвичайних ситуацій, рятувальної справи, гасіння пожеж, пожежної та техногенної безпеки, діяльності аварійно-рятувальних служб, а також гідрометеорологічної діяльності;

2) здійснення державного нагляду (контролю) за дотриманням і виконанням вимог законодавства у сфрері цивільного захисту, пожежної та техногенної безпеки, діяльності аварійно-рятувальних служб;

3) внесення на розгляд Міністра внутрішніх справ пропозицій щодо забезпечення фрормування державної політики у зазначених сорерах;

(с) В. Л. Смірнова, В. В. Репута, 2020
4) реалізація в межах повноважень, передбачених законом, державної політики у сорері волонтерської діяльності.

ДСНС, у своїй діяльності керується Конституцією та законами України, указами Президента України та постановами Верховної Ради України, прийнятими відповідно до Конституції та законів України, актами КМУ, іншими актами законодавства [3].

дСНС, відповідно до покладених на неї завдань та в межах повноважень, передбачених законом, забезпечує реалізацію державної політики 3 питань медичного та біологічного захисту населення в разі виникнення надзвичайних ситуацій; здійснює ліквідацію медико-санітарних наслідків надзвичайних ситуацій, надає екстрену медичну допомогу в зоні надзвичайної ситуації (осередку ураження) постраждалим та рятувальникам, проводить заходи 3 медичного забезпечення прикріпленого контингенту [1].

Мета роботи: дослідити систему медичного забезпечення органів і підрозділів служби цивільного захисту, її завдання та ключові повноваження. 
Матеріали і методи. Використано чинні нормативно-правові акти та керівні документи щодо організації медичного забезпечення в системі ДСНС. Методи дослідження: бібліосемантичний, аналітичний, системного підходу.

Результати дослідження та їх обговорення. У системі ДСНС України медичному обслуговуванню підлягають такі категорії осіб (далі - прикріплений контингент):

1) особи рядового і начальницького складу служби цивільного захисту (далі - особи рядового і начальницького складу);

2) курсанти та ліцеїсти навчальних закладів цивільного захисту (далі - курсанти);

3) основні працівники професійних аварійнорятувальних служб та працівники цивільного захисту (далі - рятувальники);

4) ветерани служби цивільного захисту (військової служби, органів внутрішніх справ, державної пожежної охорони), звільнені в запас (відставку) з МНС України та дСНС України (далі - ветерани);

5) особи, які, відповідно до Закону України «Про статус ветеранів війни, гарантії їх соціального захисту», мають право на користування закладами охорони здоров'я ДСНС України, у тому числі при виході на пенсію та зміні місця роботи або служби (далі - ветерани війни та прирівняні до них особи);

6) особи, звільнені зі служби цивільного захисту, визнані особами з інвалідністю внаслідок військових дій, захворювання, каліцтва, пов'язаного з виконанням службових обов'язків, та інші особи 3 інвалідністю, які отримують пенсію відповідно до Закону України «Про пенсійне забезпечення осіб, звільнених з військової служби, та деяких інших осіб» (далі - особи з інвалідністю);

7) члени сімей осіб рядового і начальницького складу, курсантів навчальних закладів цивільного захисту, загиблих під час проходження військової служби (служби цивільного захисту) (далі члени сімей загиблих) [6].

Медичне забезпечення в системі ДСНС України включає комплекс лікувально-профрілактичних, санітарно-гігієнічних, організаційно-методичних, протиепідемічних заходів та заходів медичного постачання, спрямованих на збереження життя і здоров'я осіб, зазначених вище, забезпечення оперативного медичного реагування на надзвичайні ситуації, надання своєчасної медичної допомоги рятувальникам та проведення їх медико-психологічної реабілітації, що здійснюють заклади охорони здоров'я ДСНС України.

До лікувально-профілактичних закладів сфери управління дСНС України належать: медико-санітарна частина, пункт охорони здоров'я (здоровпункт), медичний взвод та фельдшерський пункт [7]. Лікувально-профрілактичні заклади створю- ють в складі органів і підрозділів ДСНС залежно від специфіки їх діяльності та чисельності особового складу. Фінансове забезпечення лікувально-профрілактичного закладу здійснюється за рахунок коштів державного бюджету, призначених органу, підрозділу ДСНС, та інших джерел, не заборонених чинним законодавством. Матеріально-технічне, кадрове, юридичне та інші види забезпечення діяльності закладу здійснюються через відповідні структури органу, підрозділу ДСНС, до складу якого він входить. Заклади охорони здоров'я сорери управління ДСНС України провадять господарську діяльність 3 медичної практики на підставі основних принципів державної політики у сорері ліцензування на загальних засадах відповідно до Ліцензійних умов провадження господарської діяльності 3 медичної практики [2].

Завдання закладів охорони здоров'я ДСНС України визначають відповідно до основних завдань організаційних структур дСНС України, стану здоров'я, срізичного розвитку, рівня і характеру захворюваності осіб рядового і начальницького складу, умов їх розміщення (побуту), у тому числі під час виконання завдань за призначенням, санітарно-епідемічної обстановки, кліматогеографічних особливостей території (району) проведення аварійно-рятувальних робіт та масштабу медико-санітарних наслідків надзвичайних ситуацій.

Головними напрямами діяльності закладів охорони здоров'я дСНС України є:

1) надання медичної допомоги хворим у встановленому для кожного окремого закладу обсязі;

2) профрілактика захворювань;

3) організація та проведення диспансеризації;

4) проведення обов'язкових медичних оглядів кандидатів на службу до ДСНС України, осіб рядового, начальницького складу та рятувальників, курсантів навчальних закладів цивільного захисту, осіб, які бажають вступити до навчальних закладів цивільного захисту;

5) організація і проведення санаторно-курортного лікування та медико-психологічної реабілітації;

6) здійснення санітарно-гігієнічних заходів в органах, підрозділах та закладах ДСНС України;

7) організація і надання своєчасної екстреної медичної допомоги у зоні надзвичайної ситуації (осередку ураження) особам рядового і начальницького складу служби цивільного захисту, рятувальникам та іншим особам, постраждалим при ліквідації наслідків надзвичайних ситуацій, організація їх медичної евакуації до лікувальнопрофрілактичних закладів;

8) проведення організаційно-методичної роботи з питань охорони здоров'я.

Лікувально-профрілактична робота включає сукупність заходів, що проводять в органах і під- 
розділах ДСНС з метою збереження та зміцнення здоров'я прикріплених контингентів, забезпечення їх високої працездатності, попередження і зниження рівня захворюваності, працевтрат, своєчасного виявлення і лікування осіб, які захворіли, найшвидшого відновлення їхнього здоров'я.

До лікувально-профрілактичних заходів належать:

1) надання медичної допомоги прикріпленому контингенту в повсякденній діяльності та при виконанні завдань за призначенням;

2) диспансеризація та проведення динамічного нагляду прикріплених контингентів;

3) здійснення заходів щодо профрілактики інфекційних захворювань, у тому числі організація і проведення екстреної та імунопрофілактики певних інфекційних хвороб;

4) здійснення санітарно-просвітницької роботи;

5) своєчасне виявлення осіб, які захворіли, надання їм необхідної медичної допомоги;

6) відновлювальне лікування, у тому числі у відділенні реабілітації санаторно-курортного закладу ДСНС України (Міністерства оборони України, Міністерства внутрішніх справ України, центрального органу виконавчої влади, що забезпечує фрормування та реалізує державну політику в сорері охорони здоров'я, інших державних або комунальних закладах охорони здоров'я за рахунок коштів, передбачених на утримання ДСНС України);

7) санаторно-курортне лікування та проведення медико-психологічної реабілітації;

8) проведення військово-лікарської експертизи;

9) постійне вивчення та аналізування умов службової діяльності осіб рядового і начальницького складу, курсантів та рятувальників з метою виявлення факторів, що негативно впливають на їхнє здоров'я і можуть стати причиною виникнення захворювань і травм, та розроблення на основі аналізу комплексних профілактичних заходів;

10) проведення наукової, винахідницької та раціоналізаторської роботи.

Лікувально-профрілактичні заходи ґрунтуються на систематичному аналізі причин, рівня і структури поширеності захворювань, захворюваності 3 тимчасовою втратою працездатності, інвалідності осіб рядового і начальницького складу, рятувальників і курсантів та ефективності заходів 3 охорони здоров'я, у тому числі аналізі впливу неблагополучних фракторів навколишнього середовища під час ліквідації наслідків надзвичайних ситуацій.

Забезпечення санітарного та епідемічного благополуччя серед осіб рядового і начальницького складу, курсантів та рятувальників покладається на посадових осіб дСНС України та досягається шляхом створення належних санітарно-гігієніч- них умов праці та навчання, дотримання санітарно-гігієнічних та санітарно-протиепідемічних норм і правил праці, водопостачання, харчування, розміщення, побуту зазначених осіб як у повсякденній діяльності, так і під час ліквідації наслідків надзвичайних ситуацій.

3 метою недопущення виникнення та поширення інфекційних хвороб, отруєнь, радіаційних уражень серед осіб рядового і начальницького складу та рятувальників організовують і здійснюють санітарно-епідеміологічний нагляд в органах та підрозділах дСНС України.

Крім того, медичні працівники системи ДСНС України організовують і здійснюють профрілактичні заходи з метою недопущення виникнення та розповсюдження інфекційних захворювань серед осіб рядового і начальницького складу, курсантів та рятувальників, а також організовують і проводять первинні протиепідемічні заходи у разі виникнення випадків інфекційних захворювань.

При наданні медичної допомоги у закладах охорони здоров'я ДСНС України прикріплені контингенти забезпечуються безоплатно:

1) лікарськими засобами відповідно до Положення про застосування Національного переліку основних лікарських засобів під час організації процесу забезпечення населення лікарськими засобами в закладах і установах охорони здоров'я, що повністю або частково фрінансуються 3 державного та місцевих бюджетів [5];

2) виробами медичного призначення, в тому числі матеріалами для зубопротезування (за винятком протезування з дорогоцінних металів);

3) інвентарним медичним майном (тимчасово) на період лікування або реабілітації.

Медичне постачання $є$ окремою складовою загальної системи медичного забезпечення органів та підрозділів дСНС України і являє собою комплекс організаційних та практичних заходів, а саме: визначення потреби у медичному майні, його придбанні, доставці, обліку, утриманню, видачі, експлуатації, ремонту, списанні та контролю.

Забезпечення медичним майном органів і підрозділів ДСНС України організовують і здійснюють 3 метою своєчасного укомплектування їх цим майном відповідно до Норм забезпечення органів і підрозділів ДСНС України медичним майном поточного, створення та утримання певного запасу (резерву) витратного медичного майна, а також поповнення лікарськими засобами і медичними виробами спеціальних медичних укладок (комплектів, аптечок, наборів тощо) [4].

Медичне забезпечення осіб рядового і начальницького складу (рятувальників) аварійно-рятувальних підрозділів та формувань ДСНС України при ліквідації наслідків надзвичайних ситуацій здійснюється мобільними медичними пунктами, виїзними лікарськими (фрельдшерськими) брига- 
дами, які фрормуються на базі закладів охорони здоров'я ДСНС України.

У разі необхідності застосовують мобільний госпіталь ДСНС України. Госпіталь призначений для надання вторинної (спеціалізованої) та окремих видів третинної (високоспеціалізованої) медичної допомоги постраждалому населенню та рятувальникам у зонах надзвичайних ситуацій техногенного та природного характеру.

При реагуванні на надзвичайні ситуації особовим складом мобільних медичних пунктів та виїзних лікарських (срельдшерських) бригад проводяться такі заходи:

- організовується медична допомога при здійсненні маршу шляхом самодопомоги та взаємодопомоги, на привалах - визначеними медичними фрахівцями. Госпіталізація хворих на марші здійснюється у найближчі лікувальні заклади за маршрутом руху колон 3 наступною доповіддю начальнику медичної служби дСНС України;

- проводиться медична розвідка до прибуття на місце призначення, організовується взаємодія з закладами охорони здоров'я та медичними підрозділами інших центральних органів виконавчої влади для надання особам рядового і начальницького складу (рятувальникам) у разі потреби первинної і спеціалізованої медичної допомоги, а також 3 територіальними закладами Державної санітарно-епідеміологічної служби України і Державної ветеринарної та фрітосанітарної служби України (у випадку виникнення епізоотій інфекційних захворювань, спільних для людей і тварин) для організації і здійснення відповідних санітарно-гігієнічних та протиепідемічних заходів;

- надається екстрена медична допомога особам рядового і начальницького складу (рятувальникам) у пунктах розміщення аварійно-рятувальних підрозділів і в місцях проведення аварійно-рятувальних робіт, а також постраждалому населенню, що її потребує. У разі потреби здійснюється медичне сортування постраждалих та підготовка їх до евакуації у лікувальні заклади;

- організовуються та проводяться санітарно-гігієнічні та протиепідемічні заходи, зокрема медичний контроль за станом здоров'я осіб рядового і начальницького складу (рятувальників), санітарний нагляд за умовами проведення аварійно-рятувальних та інших невідкладних робіт, розміщення, харчування, водопостачання, лазне-прального обслуговування, медичної експертизи продуктів харчування та питної води, здійснюються заходи, спрямовані на зниження сприйнятливості особового складу до інфекцій;

- налагоджується взаємозв'язок медичних фрахівців аварійно-рятувальних підрозділів з медичним структурним підрозділом територіального органу ДСНС в області та місті Києві, на території якого проводяться аварійно-рятувальні роботи, і медичним структурним підрозділом ДСНС, а також організовується щоденне їх інорормування про стан медичного забезпечення та захворюваність осіб рядового і начальницького складу (рятувальників).

Після завершення аварійно-рятувальних робіт медичне забезпечення маршу аварійно-рятувальних підрозділів у пункти постійної дислокації здійснюється аналогічно медичному забезпеченню маршу в район надзвичайної ситуації. Напередодні здійснення маршу хворих, лікування яких може бути завершено в амбулаторних умовах, виписують з закладів охорони здоров'я. За наявності хворих, які залишаються в закладах охорони здоров'я, інформація про них передається територіальному органу дСНС України в області та місті Києві, на території якого проводилися аварійно-рятувальні роботи, з метою надання необхідної допомоги в організації якісного лікування цих хворих і медичному структурному підрозділу ДСНС України.

Особи, які безпосередньо брали участь у проведенні аварійно-рятувальних та інших невідкладних робіт або яких залучали до цілодобового чергування, пов'язаного з ліквідацією наслідків надзвичайної ситуації, мають право один раз на рік пройти безоплатно курс медико-психологічної реабілітації строком не менш як 14 діб, а ті 3 них, які отримали травми або брали участь у проведенні аварійно-рятувальних робіт, пов'язаних із загибеллю людей, зобов'язані пройти відповідне лікування та реабілітацію в центрах медико-психологічної реабілітації.

Медико-психологічна реабілітація являє собою комплекс лікувально-профрілактичних, реабілітаційних та оздоровчих заходів, спрямованих на відновлення психофізіологічних функцій, оптимальної працездатності, соціальної активності рятувальників аварійно-рятувальних служб (формувань), осіб, залучених до виконання аварійно-рятувальних робіт у разі виникнення надзвичайної ситуації, а також постраждалих внаслідок такої надзвичайної ситуації [6].

\section{Висновки}

Медичне забезпечення в системі ДСНС $\epsilon$ невід'ємною частиною повноважень, покладених на службу цивільного захисту. Безпосередні заходи з медичного забезпечення безперервно здійснюють заклади охорони здоров'я сорери управління ДСНС як у пунктах постійної дислокації органу, підрозділу служби цивільного захисту, так і під час виконання завдань за призначенням у зоні надзвичайної ситуації (осередку ураження) при ліквідації її наслідків й на шляху медичної евакуації. Медико-санітарну допомогу надають відповідно до державних соціальних нормативів та галузевих стандартів у сфері охорони здоров'я та вона включає весь комплекс лікувально-про- 
фрілактичних заходів на всіх рівнях надання допомоги у тісній взаємодії з закладами охорони здоров'я та медичними підрозділами інших центральних органів виконавчої влади.
Перспективи подальших досліджень полягають у розробці пропозицій щодо удосконалення чинного законодавства, яке регламентує медичне забезпечення в системі ДСНС відповідно до сучасних викликів та потреб.

\section{Список літератури}

1. Кодекс цивільного захисту України від 02.10.2012 р. № 5403-VI [Електронний ресурс] // Відомості Верховної Ради України. - 2013. - № 34-35. - Ст. 458. - Режим доступу : https://zakon.rada.gov.ua/laws/show/5403-17\#Text.

2. Про затвердження Ліцензійних умов провадження господарської діяльності з медичної практики : Постанова КМУ від 2 березня 2016 р. № 285 [Електронний ресурс] // Офіційний вісник України. - 2016. - № 30. - Ст. 1184, код акта 81591/2016. - Режим доступу : https://zakon.rada.gov.ua/laws/show/285-2016-п\#Теxt.

3. Про затвердження Положення про Державну службу України з надзвичайних ситуацій : Постанова КМУ від 16.12.2015 р. № 1052 [Електронний ресурс] // Офріційний вісник України. - 2015. - № 102. - Ст. 3514, код акта 79996/2015. - Режим доступу : https://zakon.rada.gov.ua/laws/show/1052-2015-п\#Text.

4. Про затвердження Положення про забезпечення органів і підрозділів (формувань) цивільного захисту, навчальних закладів сфери управління ДСНС України лікарськими засобами, медичними виробами та медичною технікою поточного постачання та Норм забезпечення органів і підрозділів (формувань) цивільного захисту, навчальних закладів сфрери управління ДСНС України лікарськими засобами, медичними виробами та медичною технікою поточного постачання : наказ ДСНС України від 30 травня 2014 р. № 293 [Електронний ресурс] // Верховна Рада України. - Режим доступу : https://zakon.rada.gov.ua/rada/show/v0293388-14\#Text.

5. Про затвердження Положення про застосування Національного переліку основних лікарських засобів під час організації процесу забезпечення населення лікарськими засобами в закладах і установах охорони здоров'я, що повністю або частково фрінансуються з державного та місцевих бюджетів : наказ МОЗ України від 17 липня 2017 р. № 801 [Електронний ресурс] // Верховна Рада України. - Режим доступу : https://zakon.rada.gov.ua/laws/show/z0952$17 \#$ 14.

6. Про затвердження Порядку організації медичного забезпечення в системі Державної служби України 3 надзвичайних ситуацій : наказ МВС України від 18.08.2014 р. № 831 [Електронний ресурс] // Офріційний вісник України. - 2014. - № 77. - Ст. 2208, код акта 74057/2014. - Режим доступу : https://zakon.rada.gov.ua/laws/show/ z1095-14\#Text.

7. Про затвердження Типових положень лікувально-профрілактичних закладів сфери управління МНС : наказ МНС України від 07.08.2009 р. № 552 [Електронний ресурс] // Верховна Рада України. - Режим доступу : https://zakon. rada.gov.ua/laws/show/z1095-14\#Text.

\section{References}

1. (2013). Kodeks tsyvilnoho zakhystu Ukrainy vid 02.10.2012 № 5403-VI [Code of Civil Defense of Ukraine of October 02, 2012 No. 5403-VI]. Vidomosti Verkhovnoi Rady Ukrainy - Bulletin of the Verkhovna Rada of Ukraine, 34-35, 1802. Retrieved from: https://zakon.rada.gov.ua/laws/show/5403-17\#Text [in Ukrainian].

2. (2016). Postanova KMU vid 2 bereznia 2016 № 285 «Pro zatverdzhennia Litsenziinykh umov provadzhennia hospodarskoi diialnosti z medychnoi praktyky» [Resolution of the Cabinet of Ministers of March 2, 2016 No. 285 "On approval of licensing conditions for economic activity in medical practice"]. Ofitsiinyi visnyk Ukrainy - Official Bulletin of Ukraine, 30, 18. Retrieved from: https://zakon.rada.gov.ua/laws/show/285-2016-p\#Text [in Ukrainian].

3. (2015). Postanova KMU vid 16.12.2015 № 1052 «Pro zatverdzhennia Polozhennia pro Derzhavnu sluzhbu Ukrainy z nadzvychainykh sytuatsii» [Resolution of the Cabinet of Ministers of December 16, 2015 No. 1052 "On approval of the Regulations on the Civil Service of Ukraine for Emergencies"]. Ofitsiinyi visnyk Ukrainy - Official Bulletin of Ukraine, 102, 40. Retrieved from: https://zakon.rada.gov.ua/laws/show/1052-2015-p\#Text [in Ukrainian].

4. (2014). Nakaz DSNS Ukrainy vid 30 travnia 2014 № 293 «Pro zatverdzhennia Polozhennia pro zabezpechennia orhaniv i pidrozdiliv (formuvan) tsyvilnoho zakhystu, navchalnykh zakladiv sfery upravlinnia DSNS Ukrainy likarskymy zasobamy, medychnymy vyrobamy ta medychnoiu tekhnikoiu potochnoho postachannia ta Norm zabezpechennia orhaniv i pidrozdiliv (formuvan) tsyvilnoho zakhystu, navchalnykh zakladiv sfery upravlinnia DSNS Ukrainy likarskymy zasobamy, medychnymy vyrobamy ta medychnoiu tekhnikoiu potochnoho postachannia» [Order of the SES of Ukraine of May 30, 2014 No. 293 "On approval of the Regulations on the provision of bodies and units (formations) of civil defense, educational institutions in the field of SES of Ukraine drugs, medical devices and medical equipment current supply and Standards of bodies and units (formations) ) civil protection, educational institutions of the SES of Ukraine with medicines, medical devices and medical equipment of current supply"]. Verkhovna Rada Ukrainy - Verkhovna Rada of Ukraine. Retrieved from: https://zakon.rada. gov.ua/rada/show/v0293388-14\#Text [in Ukrainian].

5. (2017). Nakaz MOZ Ukrainy vid 17 lypnia 2017 № 801 «Pro zatverdzhennia Polozhennia pro zastosuvannia Natsionalnoho pereliku osnovnykh likarskykh zasobiv pid chas orhanizatsii protsesu zabezpechennia naselennia likarskymy zasobamy v zakladakh i ustanovakh okhorony zdorovia, shcho povnistiu abo chastkovo finansuiutsia z derzhavnoho ta mistsevykh biudzhetiv» [Order of the Ministry of Health of Ukraine of July 17, 2017 No. 801 "On approval of the Regulations on the use of the National List of Essential Medicines in organizing the process of providing the population with medicines in health care facilities and institutions fully or partially funded from state and local budgets"]. Verkhovna Rada Ukrainy - Retrieved from: https://zakon.rada.gov.ua/laws/show/z0952-17\#n14 [in Ukrainian]. 
6. (2014). Nakaz MVS Ukrainy vid 18.08.2014 № 831 «Pro zatverdzhennia Poriadku orhanizatsii medychnoho zabezpechennia v systemi Derzhavnoi sluzhby Ukrainy z nadzvychainykh sytuatsii» [Order of the Ministry of Internal Affairs of Ukraine dated 18.08.2014 No. 831 "On approval of the Procedure for the organization of medical care in the system of the State Service of Ukraine for Emergencies"]. Ofitsiinyi visnyk Ukrainy - Official Bulletin of Ukraine, 77, 376. Retrieved from: https://zakon.rada.gov.ua/laws/show/z1095-14\#Text [in Ukrainian].

7. (2009). Nakaz MNS Ukrainy vid 07.08.2009 № 552 «Pro zatverdzhennia typovykh polozhen likuvalno-profilaktychnykh zakladiv sfery upravlinnia MNS» [Order of the Ministry of Emergencies of Ukraine dated August 07, 2009 No. 552 "On approval of the Standard provisions of treatment and prevention facilities of the Ministry of Emergencies"]. Verkhovna Rada Ukrainy - Retrieved from: https://zakon.rada.gov.ua/laws/show/z1095-14\#Text [in Ukrainian].

\section{PLACE AND ROLE OF MEDICAL SUPPORT IN THE SYSTEM OF THE STATE EMERGENCY SERVICE OF UKRAINE}

V. L. Smirnova ${ }^{1}$, V. V. Reputa ${ }^{2}$

${ }^{1}$ I. Horbachevsky Ternopil National Medical University, Ternopil, Ukraine

${ }^{2}$ Emergency Rescue Detachment of Special Purpose of the Department of the SES of Ukraine in Ternopil region, Ternopil, Ukraine

Purpose: to investigate the system of medical support of units and divisions of the civil protection service, its tasks and key authorities.

Materials and Methods. Current regulations and guiding documents on the organization of medical support in the State Emergency Service (SES) system were used. Research methods: biblio-semantic, analytical, systemic approach.

Results. The article defines the tasks of the medical service in the context of the main authorities of the SES to ensure the implementation of state policy on medical and biological protection of the population in case of emergencies; elimination of medical and sanitary consequences of emergencies, providing emergency medical care in the emergency zone (affected area) to victims and rescuers, measures to provide medical support to the attached contingent, which are carried out by health care facilities of the SES. The main directions of activity of health care institutions of the State Emergency Service are considered, namely treatment and prophylactic, sanitation and hygienic, organizational and methodical, anti-epidemic, medical provision, medical and psychological rehabilitation.

Conclusions. Medical support in the SES system is an integral part of the authorities of the civil protection service. Direct measures of the medical support are continuously carried out by health care facilities in the sphere of management of the SES, both in the areas of permanent deployment of the unit, division of the civil protection service, and during assignment tasks in the emergency zone (affected area), en route of the medical evacuation. Health care services provided in accordance with state social norms and industry standards in the field of health care and includes a full range of treatment and prevention measures at all levels of care in close cooperation with health care facilities and medical units of other central executive bodies.

KEY WORDS: medical support; civil protection service; State Emergency Service of Ukraine.

Рукопис надійшов до редакції 10.06.2020 р.

\section{Відомості про авторів:}

Смірнова Валентина Леонідівна - кандидат медичних наук, доцент кафедри громадського здоров'я та управління охороною здоров'я Тернопільського національного медичного університету імені І. Я. Горбачевського МО3 України; тел.: +38(0352) 52-72-33.

Репута Віктор Володимирович - магістр медицини, старший лейтенант служби цивільного захисту, начальник (лікар) Пункту охорони здоров'я Аварійно-рятувального загону спеціального призначення управління Державної служби України з надзвичайних ситуацій у Тернопільській області; тел.: +38(0352) 26-80-06. 